\title{
SPATIAL DISTRIBUTION OF CHROMIUM AND LEAD IN THE BENTHIC ENVIRONMENT OF COASTAL AREAS OF THE RÍO DE LA PLATA ESTUARY (MONTEVIDEO, URUGUAY)
}

\author{
MUNIZ, P., ${ }^{1,2}$ VENTURINI, N. ${ }^{1,2}$ and GÓMEZ-ERACHE, M. ${ }^{1}$ \\ ${ }^{1}$ Sección Oceanología, Departamento de Ecología, Facultad de Ciencias, Iguá, 4225, Montevideo, 11400 Uruguay \\ ${ }^{2,3}$ Instituto Oceanográfico da Universidade de São Paulo, Praça do Oceanográfico, 191, \\ São Paulo, CEP 05508-900, SP, Brazil \\ Correspondence to: Pablo Muniz, Instituto Oceanográfico da Universidade de São Paulo, Praça do Oceanográfico, \\ 191, São Paulo, CEP 05508-900, SP, Brazil, e-mail: pmmaciel@usp.br; pmmaciel@fcien.edu.uy \\ Received October 21, 2002 - Accepted February 21, 2003 - Distributed February 29, 2004
}

(With 6 figures)

\begin{abstract}
Twenty-four sediment samples were collected seasonally during one year from the partially closed Montevideo Bay and the adjacent coastal zone, in Uruguay, in order to determine the impact of chromium and lead in the sediments. Analysis of related environmental variables included bottom water temperature, salinity, $\mathrm{pH}$, dissolved oxygen, and several sedimentological variables such as redox potential and total organic matter. Concentrations and range of variation of these two metals were similar to those found in urbanized and industrialized estuarine environments. Metal enrichment is higher in the bay than in the adjacent coastal zone, however an important increase especially in $\mathrm{Pb}$ content was detected in an area previously considered as a pristine one. Considering both metal content and benthic environment characteristics, the study area can be clearly divided in at least two well-defined regions. One is the inner region of the bay near the streams, and the outermost stations of the bay and the adjacent coastal zone form the other. The first one can be considered highly polluted and the other moderately polluted. The values of the metals studied indicated that adverse biological effects are probably occurring, specially in the innermost region of Montevideo Bay.
\end{abstract}

Key words: benthic environment, lead, chromium, Río de la Plata, Uruguay.

\section{RESUMO}

\section{Distribuição espacial de cromo e chumbo no ambiente bentônico de regiões costeiras do estuário do Río de la Plata (Montevidéu, Uruguai)}

Com o intuito de determinar o impacto do cromo e do chumbo na Bahía de Montevidéu e na zona costeira adjacente, foram coletadas sazonalmente, durante um ano, 24 amostras de sedimento de fundo. Simultaneamente, foram analisadas amostras para temperatura, salinidade, $\mathrm{pH}$ e oxigênio dissolvido da água de fundo, além de diversas variáveis sedimentológicas, como potencial redox, matéria orgânica total, entre outras. As concentrações das duas espécies de metais estudadas foram similares às reportadas na literatura para áreas estuarinas industrializadas e urbanizadas. $\mathrm{O}$ enriquecimento metálico foi maior na baía do que na área costeira adjacente (Punta Carretas e Punta Yeguas), embora um importante enriquecimento, especialmente de chumbo, fosse observado na região de Punta Yeguas, área previamente considerada não impactada. Tendo por base o conteúdo de metais e as características do ambiente bentônico, a área de estudo pode claramente ser dividida em, ao menos, duas regiões distintas. Uma corresponde à região mais interna da Bahía de Montevidéu, perto da desembocadura dos arroios, e a outra, à região mais externa da baía e à região costeira adjacente. A primeira pode ser considerada 
altamente poluída e a segunda, moderadamente. As concentrações dos metais estudados indicaram que estes provavelmente causam efeito biológico adverso, especialmente sobre a macrofauna, sendo mais acentuado na região interna da baía.

Palavras-chave: ambiente bentônico, chumbo, cromo, Río de la Plata, Uruguai.

\section{INTRODUCTION}

Throughout the twentieth century, shallow estuarine and marine coastal ecosystems have been suffering incremental impact due to their usage as reservoirs for multiple types of wastes. Contaminants enter estuarine waters via several key routes, specially direct pipeline discharges from coastal cities, riverine inputs, atmospheric deposition, and nonpoint source runoff from land (Kennish, 1992). Urban development and the industrialization of the coastal zones have promoted a continuous increase in heavy metal contamination in estuarine areas. Bottom sediments in particular act as a sink or a source of pollutants, depending on the prevalent physical and chemical conditions and their sedimentological characteristics.

Montevideo Bay and the surrounding coastal area are located in the fluvial-marine system of the Río de la Plata. Hydrographic characteristics are determined by dynamic interactions between fresh and marine waters. Wind and river discharge control the seasonal variability of the salinity and turbidity fields in the upper layer, while diluted shelf waters occupy the bottom layer (Guerrero et al., 1997). The study area is located within the salinity and turbidity frontal zone of the Río de la Plata (Nagy et al., 1987; López-Laborde \& Nagy, 1999; Framiñán \& Brown, 1996; Framiñán et al., 1999), characterized by an estuarine turbidity maximum (ETM) related to gravitational circulation and clay particle floculation which develops in the transitional "null zone" between the tidal river and the estuarine region (Nagy et al., 1987; López-Laborde \& Nagy, 1999). The ETM is usually associated with the salt intrusion limit $(0.5)$ and the suspended matter reaches 0.6$0.8 \mathrm{~g} \mathrm{~L}^{-1}$ or more near the bottom (López Laborde $\&$ Nagy, 1999).

The study area comprises three different portions of the Montevideo coastal zone. Montevideo Bay is a semi-enclosed urban bay that receives large amounts of domestic and industrial sewage through the Pantanoso and Miguelete streams and also contains Montevideo Harbour, the UTE water steam plant, and the ANCAP refinery. The Punta Carretas region, situated eastward, is the site of Uruguay's largest submarine pipe in which the sewage from the east portion of Montevideo city is concentrated. Finally, Punta Yeguas, located westward and considered a pristine zone, is currently viewed by the Municipal Government as the ideal area in which to construct a new submarine pipe with characteristics similar to that of Punta Carretas. This pipe will be concentrate the sewage from the west portion of the city, including what is presently being discharged directly into Montevideo Bay waters.

In order to assess the environmental quality of the Montevideo coastal zone, we studied the distribution of chromium and lead sediment contents during one year in a segment of Montevideo Coastal zone that a priori is experiencing the effects of different impact intensities.

\section{MATERIAL AND METHODS}

\section{Data collection and laboratory methods}

In August 1998 (winter), September 1998 (spring), February 1999 (summer), and April 1999 (fall), following the same schedule, sediment and water bottom samples were collected at 24 locations in the Montevideo coastal zone (Fig. 1). Stations A to J, located in Montevideo Bay, were sampled using a small boat. Stations K to X, located in Punta Carretas and Punta Yeguas, were sampled on board the Uruguayan Army vessel "ROU 27 Banco Ortíz".

At each station, 4 sediment samples were taken with a manual acrylic corer having a $4.5 \mathrm{~cm}$ internal diameter. Sediments taken with the first corer were submitted to the standard dry-sieve and pipette method (Suguio, 1973) and parameters described by Folk \& Ward (1957) were calculated for sedimentological data. The redox potential of the sediment, was determined following the methodology described in Sommaruga (1987), using the standard solution of Zobell (1946). Another corer sample was used to obtain the total organic matter content of 
surface sediments, using the calcination technique (Byers et al., 1978). Finally, the last corer sample was divided into three horizons (0-6, 7-12, 13-18 $\mathrm{cm}$ depth) to determine the chromium and lead content of surface, middle, and bottom sediments. The sediments that passed through a PE-mesh of $63 \mu \mathrm{m}$ were dried at $85^{\circ} \mathrm{C}$ to constant weight, prior to homogenization by an agate mortar and pestle. In order to avoid interference of organic matter in the results, and to convert the metals to their free form, we applied method n. 3051 of the EPA (1990). Duplicates of subsamples (0.5-1 g) were mixed with $10 \mathrm{ml}$ concentrated nitric acid and digested by microwave (CEM, MDS 2100) in a closed fluorocarbon vessel. Quantification was done by ASS (Shimadzu AA-680) with graphite furnace atomization (Shimadzu GFA-4B). Quality control involved procedural blanks, measurement by standards obtained from the National Institute of Standards and Technology, and spiked samples. Results presented in $\mu \mathrm{g} \mathrm{g}^{-1}$ dry sediment $(<63 \mu \mathrm{m})$ correspond to mean values by duplicate analyses. Variation between duplicates was always less than 5\%.

Bottom water samples were obtained using Hydro-Bios ${ }^{\circledR}$ bottles in order to measure temperature and to determine dissolved oxygen content by the Winkler titration method (Grasshoff, 1983). Salinity and $\mathrm{pH}$ were ascertained using an $\mathrm{YSI}^{\circledR}$ multiparameter.

\section{Data analysis}

The index of geoaccumulation $\left(I_{\text {geo }}\right)$ introduced by Muller (1981) was used as a measure of metal pollution in the sediments: $I_{\text {geo }}=-\log _{2} \mathrm{Cn} /(1.5 * \mathrm{Bn})$, where $\mathrm{Cn}$ is the measured concentration of the metal in unpolluted sediments and $\mathrm{Bn}$ is the concentration of the metal in the sample analyzed. According to this index, samples were divided into five groups: unpolluted $\left(I_{\text {geo }}<1\right)$, very low polluted $\left(1<I_{\text {geo }}<\right.$ $2)$, low polluted $\left(2<I_{\text {geo }}<3\right)$, moderate polluted $\left(3<I_{\text {geo }}<4\right)$, highly polluted $\left(4<I_{\text {geo }}<5\right)$, and very highly polluted $\left(I_{g e o}>5\right)$. The index has been utilized to assess metal enrichment of riverine (Herr \& Gray, 1997) and estuarine sediments (Ruiz, 2001). As the background level $(\mathrm{Cn})$, we chose data generated in previous studies, one performed by Moyano et al., (1993) in the Montevideo coastal zone and the other by Thompson et al. (1987) for estuarine temperate sediments.

A Spearman correlation analysis was performed to determine the degree of relationship between chromium and lead contents and the other environmental variables studied at a seasonal scale, considering 5\% as $p$-level. Finally, an environmental variable (included $\mathrm{Cr}$ and $\mathrm{Pb}$ content) per sampling sites matrix was constructed to perform a principal components analysis (PCA), also at a seasonal scale (four PCA), using the computer software STATISTICA $^{\circledR}$ (StatSoft, 1995).

\section{RESULTS}

\section{Hydrological and surface sediment characteristics}

Bottom water temperatures were almost constant in each survey, however some stations of the innermost region of the bay always showed temperatures one or two degrees higher, probably due to the activity of the UTE steam water plant (Fig. 2). Salinity varied from 0.5 to more than 25 , clearly increasing towards the outermost sector of Montevideo Bay and the adjacent coastal zone, except in the fall, when salinity greatly decreases at $\mathrm{V}, \mathrm{W}$, and $\mathrm{X}$ stations due to Montevideo Bay water discharge. Only in the spring survey, was salinity more constant in all sampling stations (Fig. 2). Dissolved oxygen concentrations showed great variation (1 to $8.45 \mathrm{mg} \mathrm{L}^{-1}$ ), always with the lowest values registered and several hypoxia events in the inner region of the bay (Fig. 2). Bottom waters presented acid $\mathrm{pH}$ values (5.97) in the inner Montevideo Bay stations and basic pH (8.03) towards the surrounding coastal area (Fig. 2).

In sediment samples, silt was the dominant fraction with little variation between the surveys. Generally, this fraction was around $50 \%$ to $90 \%$ (Fig. 3 ), but some exceptions were detected, usually in stations $\mathrm{C}, \mathrm{E}, \mathrm{F}$, and $\mathrm{G}$, where sand contribution was more important (Fig. 3). The most inner stations of Montevideo Bay also presented more heterogeneity in their sediment composition. On the other hand, Punta Carretas and Punta Yeguas stations always showed a very homogeneous sediment composition with a very low contribution of sand ( $2 \%$ to $8 \%$, Fig. 3 ). In these stations, clay and sand fractions presented similar contributions.

Total organic matter content in surface sediments was high, reaching values of $12.8 \%$ (station E, summer; Fig. 3). Once again, the adjacent coastal zone of the bay showed more constant values in each survey. There was not a clear seasonal trend; only the inner region of Montevideo Bay seemed to have higher values in summer (Fig. 3). 


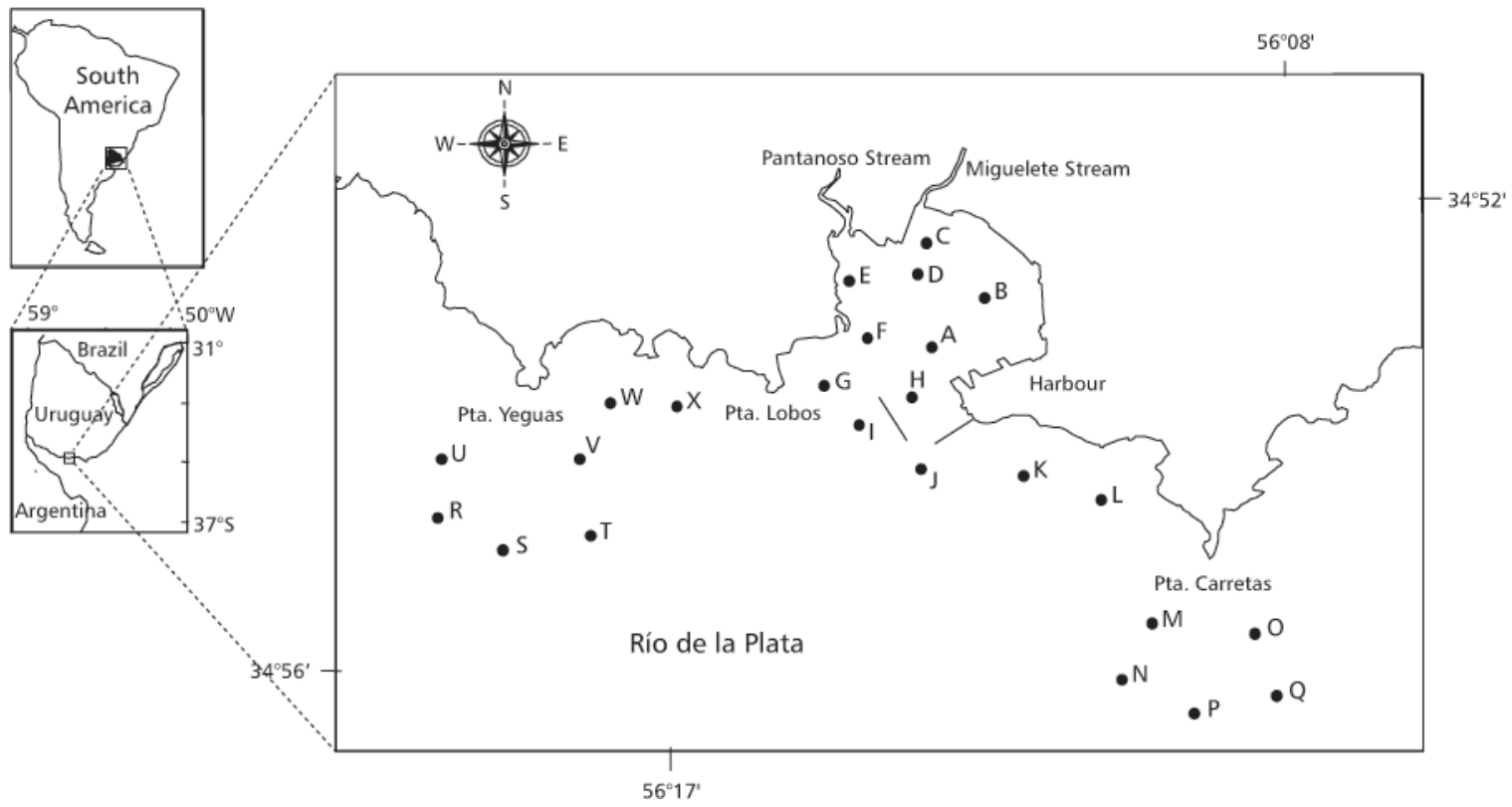

Fig. 1 - Map of the study area showing the location of the twenty-four sampling stations (A to X black dots).
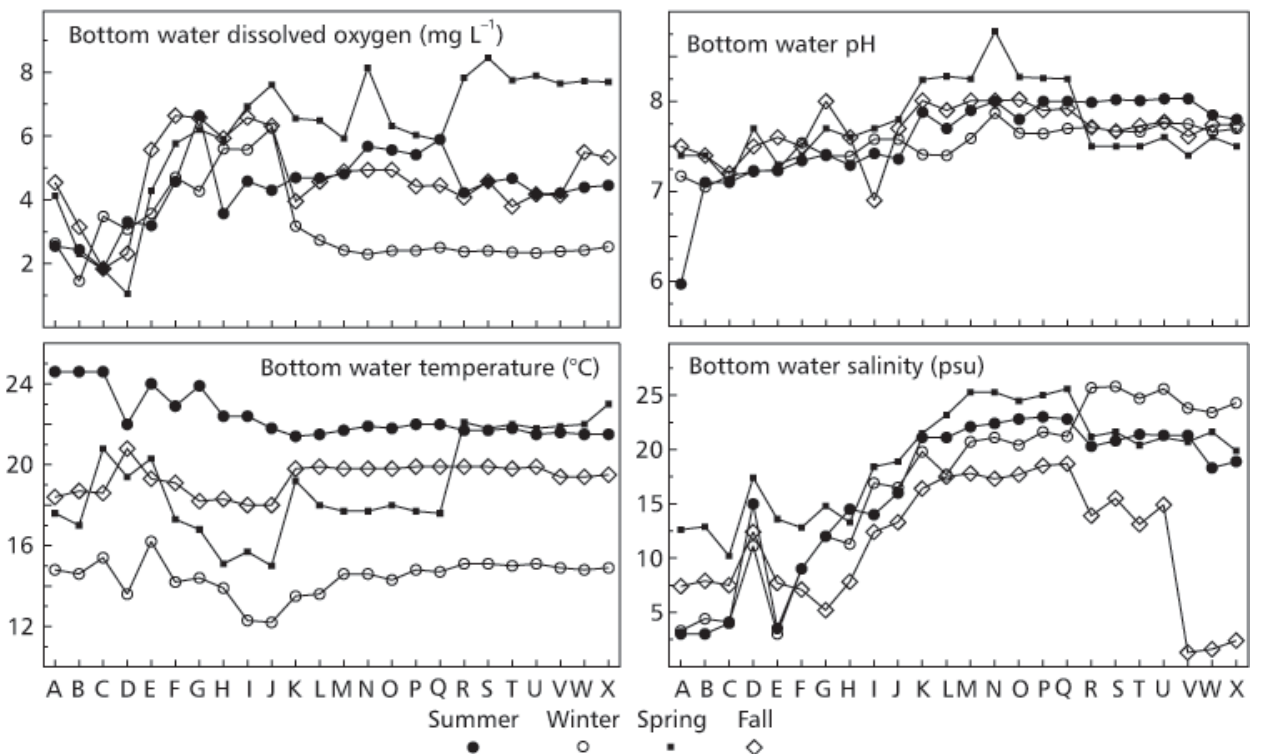

Fig. 2 - Bottom water dissolved oxygen concentrations, pH, temperature, and salinity in the 24 sampling stations (A to $\mathrm{X}$ ) for summer, winter, spring, and fall surveys. 

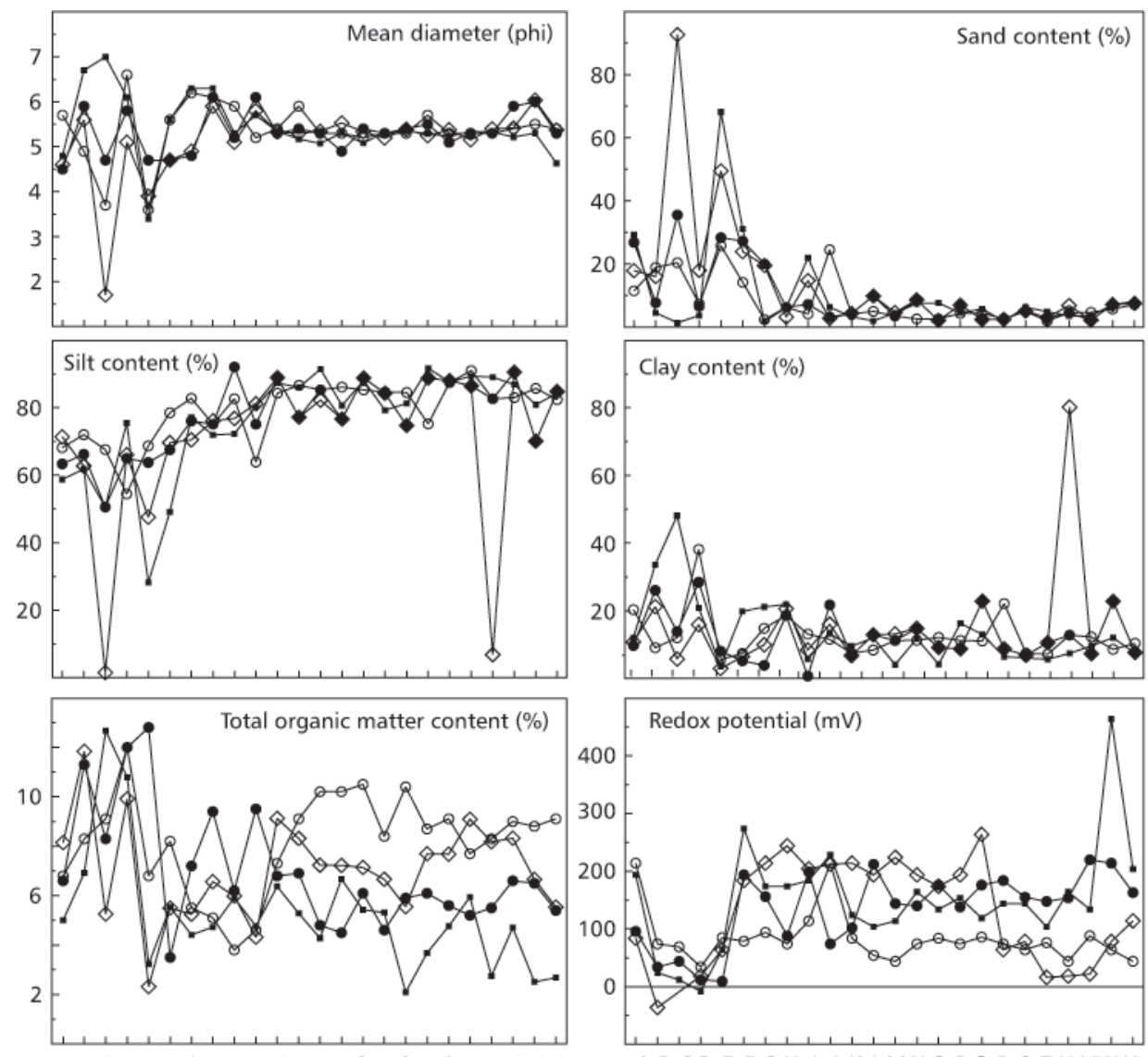

Summer Winter Spring Fall

Fig. 3 - Mean diameter, sand, silt, clay, total organic matter content, and redox potential in sediment samples of the 24 stations (A to $\mathrm{X}$ ) for summer, winter, spring, and fall surveys.

In general, redox potential (Eh) was low, indicating a tendency to anoxic conditions within the first sediment centimeters; values were higher in the Punta Carretas and Punta Yeguas regions than in the inner region of the bay (Fig. 3). Values showed anoxic conditions $(\cong<200 \mathrm{mV})$ in the majority of the sampling stations, but were recorded more frequently in the innermost stations of Montevideo Bay, especially in stations B, C, and D. The Eh values showed the same trend of dissolved oxygen bottom values.

\section{Chromium concentrations}

The range of $\mathrm{Cr}$ variation in the sediment column was higher in Montevideo Bay than in the regions of Punta Carretas and Punta Yeguas. Some inner stations of Montevideo Bay (A, B, C, and D) presented lower values in the first $6 \mathrm{~cm}$ of the sediment column than in the deeper ones. However, the majority of the data showed no clear pattern and we decided to work with mean values per sampling station. Stations C, D, and E always showed higher values and higher variation in the sediment column and among the four surveys (Fig. 4). The minimum value recorded was $29.5 \mathrm{mg} \mathrm{kg}^{-1}$ (station $\mathrm{S}$, winter), and the maximum $1032.03 \mathrm{mg} \mathrm{kg}^{-1}$ (station D, spring). Little variation among the surveys in Punta Carretas and Punta Yeguas regions was observed (Fig. 4). Chromium content was positively correlated (Table 1) with lead and with the total organic matter content (spring and summer surveys). Negative correlations were found with the Eh (spring and summer surveys), with the $\mathrm{pH}$ (summer and winter surveys), and salinity (only in winter survey). 
The $I_{g e o}$ values showed that the Punta Carretas and Punta Yeguas areas (stations K to X) can be classified as highly polluted (mean annual values between 4 and 5, Fig. 5). Temporally, values around 3.5 of $I_{g e o}$, indicating a moderate pollution state (Table 2), were recorded only in fall.

\section{Lead concentrations}

Like chromium, lead variation within the sediment column was high in the inner stations of Montevideo Bay but without any clear pattern of variation and, again, some inner stations of Montevideo Bay (e.g., stations B, C, and D) showed elevated values towards the bottom of the sediment column. The minimum value recorded was $5.61 \mathrm{mg} \mathrm{kg}^{-1}$ (station $\mathrm{G}$, winter) and the maximum was $642.58 \mathrm{mg} \mathrm{kg}^{-1}$ (station C, spring) (Fig. 4). Both spatially and temporally the smallest variations were recorded in the Punta Carretas and Punta Yeguas regions (Fig. 4). Significant positive correlations were obtained with $\mathrm{Cr}$ content (excepted in the spring survey), total organic matter, clay content, and bottom water temperature (only in summer, Table 1). On the other hand, negative correlations were obtained with the bottom water dissolved oxygen content, Eh, $\mathrm{pH}$ (in winter and summer), and salinity (in spring and summer, Table 1).

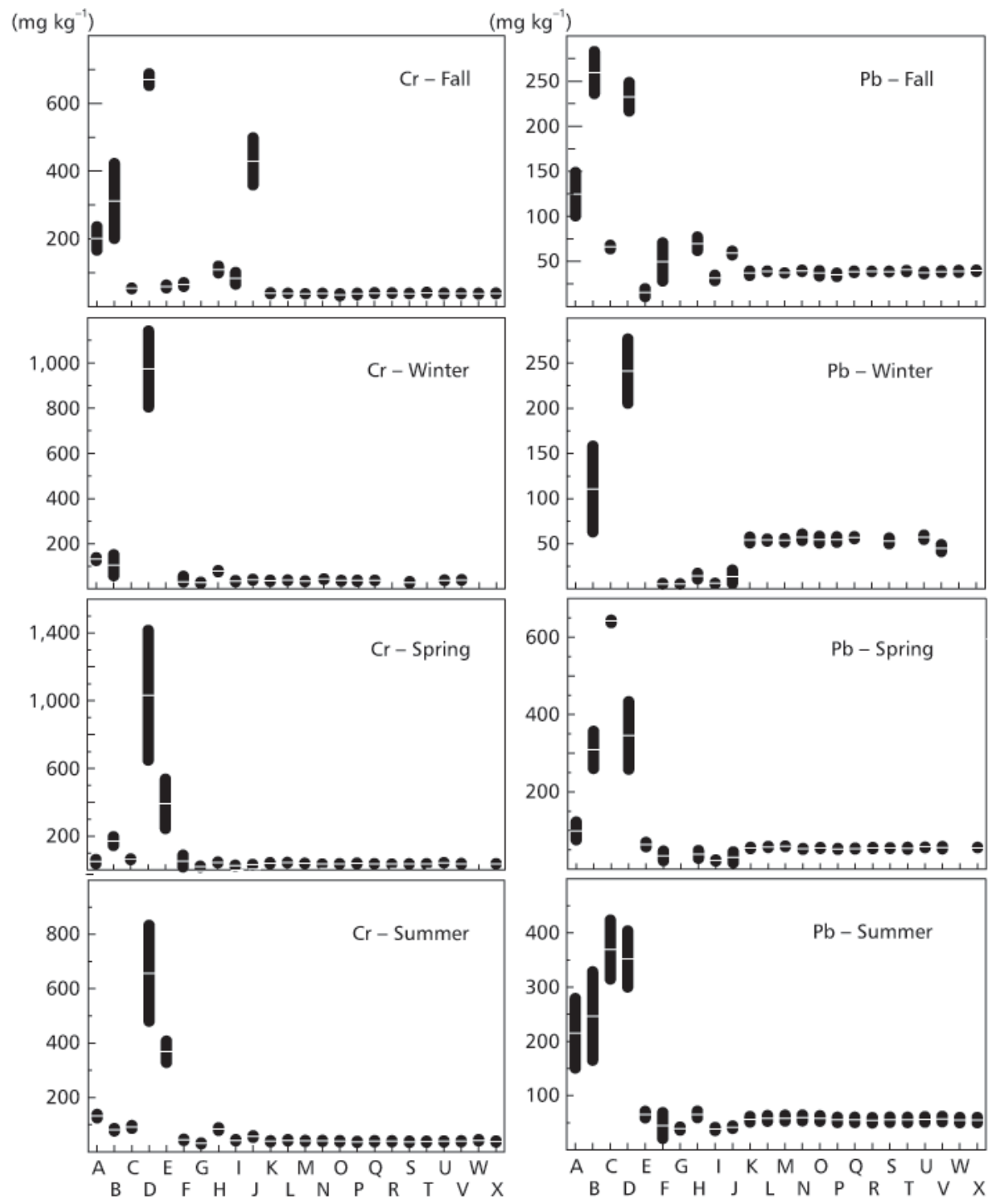

Fig. 4 - Mean values and two standard deviations $( \pm)$ of chromium and lead concentrations in the sediments of the 24 sampling stations (A to $\mathrm{X}$ ) for fall, winter, spring, and summer surveys. 
Annual mean values of $I_{\text {geo }}$ (Fig. 5) ranged from 2.5 (low polluted) to 6.6 (very highly polluted), and values of around 4 were recorded at stations $\mathrm{K}$ to $\mathrm{X}$ (moderate to highly polluted). Temporally, the stations of Montevideo Bay showed the lowest values of $I_{\text {geo }}$ in the winter survey (Table 2), with values of 1 at stations F, G, and I, indicating unpolluted sediments. In Punta Carretas and Punta Yeguas stations, the lower values were recorded in the fall (Table 2), indicating moderate pollution. The inner bay stations A, B, C, and D always presented the highest values and so can be considered very highly polluted.

\section{Multivariate analysis}

The four PCAs performed confirmed the trends showed by the data. They always revealed at least two well-defined groups of stations (Fig. 6 ), clearly separating the inner stations of Montevideo Bay from the remainder. The first and second components together explained $73.1 \%$ of the variance in summer, $73.7 \%$ in spring, $70 \%$ in the fall, and $68.2 \%$ in winter. Table 3 shows the loading of the different variables for each PCA performed and the percentage of explanation of the first two components.

\section{DISCUSSION}

One of the main features of the Río de la Plata is a marked estuarine front (ETF) located close to the $5 \mathrm{~m}$ isobath ("Barra del Indio") and associated with low salinities (Framiñán \& Brown, 1996; Nagy et al., 1997). Retention processes appear to be favoured in partially mixed estuaries like the Río de la Plata, which develop turbidity maximum zones (Nagy et al., 1997).

Retention processes are complex and are also promoted by flocculation of fine particles crossing the freshwater-seawater interface (Duck \& Wewetzer, 2001). Silty fractions dominate the outermost stations of Montevideo Bay, as well as the bottom surface sediments of Montevideo Harbour (Danulat et al., 2002). This is in accordance with the general sedimentary pattern determined for the Río de la Plata estuary (López-Laborde, 1997).

Redox potential (Eh) evidenced lack of oxygen in surface sediments at most stations. Strongly reduced conditions were detected at sampling stations A, B, $\mathrm{C}, \mathrm{D}$, and $\mathrm{E}$, where redox potential at $1 \mathrm{~cm}$ depth reached values of around $0 \mathrm{mV}$ (Fig. 3). The Eh is a good indicator of the presence of oxygen and organic matter in the sediment (Pezeshki \& Delaune, 1993) and consequently it serves as a guide to its biological conditions (Pearson \& Stanley, 1979).

TABLE 1

Results of the correlation analysis between $\mathrm{Cr}, \mathrm{Pb}$, and the environmental variables analyzed, for each survey in the 24 sampling stations in Montevideo coastal zone. Only significant correlations at $p<0.05$ are showed.

\begin{tabular}{|c|c|c|c|c|c|c|c|c|c|c|c|c|c|c|c|}
\hline \multicolumn{4}{|c|}{ Summer } & \multicolumn{4}{|c|}{ Winter } & \multicolumn{4}{|c|}{ Spring } & \multicolumn{4}{|c|}{ Fall } \\
\hline \multicolumn{2}{|r|}{$\mathrm{Cr}$} & \multicolumn{2}{|r|}{$\mathbf{P b}$} & \multicolumn{2}{|r|}{$\mathrm{Cr}$} & \multicolumn{2}{|r|}{$\mathbf{P b}$} & \multicolumn{2}{|r|}{$\mathrm{Cr}$} & \multicolumn{2}{|r|}{$\mathbf{P b}$} & \multicolumn{2}{|c|}{$\mathrm{Cr}$} & \multicolumn{2}{|r|}{$\mathbf{P b}$} \\
\hline+ & $\mathrm{Pb}$ & + & $\mathrm{Cr}$ & + & $\mathrm{Pb}$ & + & $\mathrm{Cr}$ & + & TOM & + & \% Clay & + & $\mathrm{Pb}$ & + & $\mathrm{Cr}$ \\
\hline+ & TOM & + & Temp & + & $\%$ Clay & + & $\%$ Clay & - & Oxyg & + & DM & & & + & TOM \\
\hline- & $\mathrm{pH}$ & + & $\%$ Clay & - & $\mathrm{pH}$ & + & TOM & - & Eh & + & TOM & & & - & Oxyg \\
\hline- & $\%$ Silt & + & TOM & - & Salin & - & PH & & & - & Depth & & & - & $\mathrm{Eh}$ \\
\hline- & Eh & - & Depth & - & $\%$ Silt & - & $\%$ Silt & & & - & Salin & & & & \\
\hline- & Eh & - & Oxyg & & & & & & & - & Oxyg & & & & \\
\hline & & - & Salin & & & & & & & - & Eh & & & & \\
\hline & & - & $\mathrm{pH}$ & & & & & & & & & & & & \\
\hline & & - & Eh & & & & & & & & & & & & \\
\hline & & - & $\%$ Silt & & & & & & & & & & & & \\
\hline
\end{tabular}

TOM = Total organic matter; $\%$ Silt = percentage of silt; $\mathrm{Eh}=$ redox potential; Temp = temperature; Salin = salinity; $\mathrm{DM}=$ mean diameter; Oxyg $=$ oxygen concentration. 

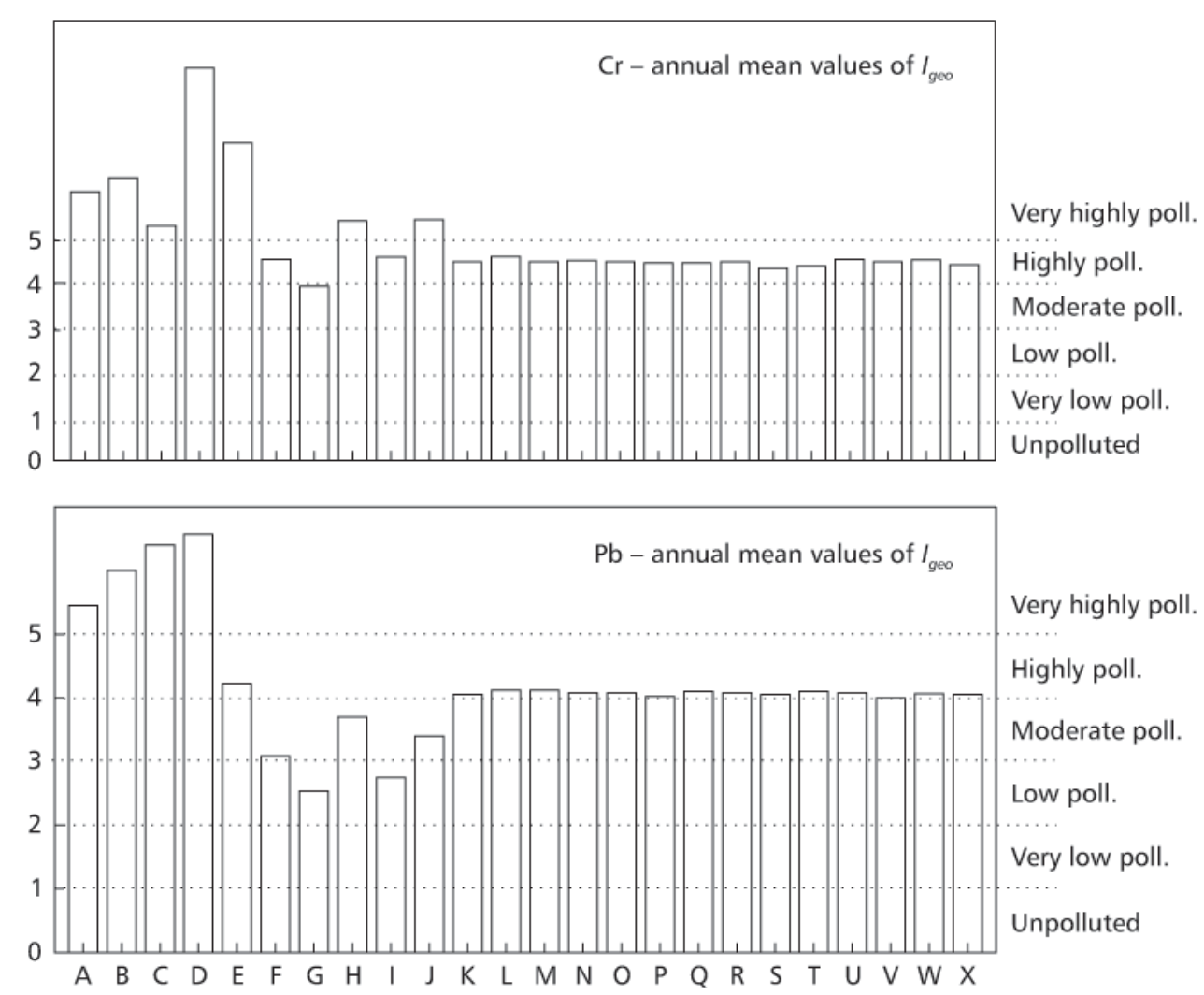

Fig. 5 - Annual mean values of the index of geoaccumulation $\left(I_{\text {geo }}\right)$ for chromium and lead in the sediment samples of the 24 stations (A to X).

Generally, Eh tends to be lower in finer sediments (Gray, 1981). The high oxygen demand induced by the decomposition of large amounts of organic matter in the innermost stations of the bay, can explain the small redox potential values found. These shallower stations receive inland inputs of organic material through the Pantanoso and Miguelete streams.

The organic matter content of the sediments can be considered high when compared to nearby regions (Ieno \& Bastida, 1998; Muniz \& Venturini, 2001; Danulat et al., 2002), higher values are registered in the inner region of the bay than at the remaining stations. Smaller sediment fractions (silt and clay) generally correlate with the organic matter content.

Organic particles are adsorbed onto clay fractions, which are negatively charged and have a relatively large surface area, forming sedimentation complexes (Sharp, 1973). The deposition of these complexes commonly occurs in areas of small hydrodynamic energy, producing the organic enrichment of the sediments and, consequently, depletion in oxygen concentration.

The spatial gradient recorded for the organic matter is, without any doubt, a consequence of the high organic load that the innermost part of the bay receives due to anthropogenic activities. The major population and industrial centers in Uruguay are concentrated in the Montevideo coastal zone. The relatively high trace metal enrichment in this area is, therefore, likely to originate in past and present inputs. Relations between enhanced trace metal concentrations and cities have been observed in other studies carried out in the Río de la Plata (Masello et al., 1996) and South Atlantic estuaries (Lacerda et al., 1988; Baisch et al., 1988). Only in the inner stations of Montevideo Bay were temporal differences in $\mathrm{Cr}$ and $\mathrm{Pb}$ concentrations observed, perhaps because of the greater heterogeneity in the sedimentary environment, especially at stations $\mathrm{C}$ and $\mathrm{E}$, located at the mouth of the Miguelete and Pantanoso Streams (Fig. 3, 4, and Table 2). 
TABLE 2

Geoaccumulation Index $\left(I_{g e o}\right)$ values for $\mathrm{Cr}$ and $\mathrm{Pb}$ levels calculated for each survey in the 24 sampling stations in Montevideo coastal zone.

\begin{tabular}{|c|c|c|c|c|c|c|c|c|}
\hline \multicolumn{5}{|c}{ CHROMIUM } & \multicolumn{5}{c|}{ LEAD } \\
\hline Stations & Summer & Winter & Spring & Fall & Summer & Winter & Spring & Fall \\
\hline A & 6.3 & 6.3 & 4.9 & 6.9 & 6.2 & 5.2 & 5.0 & 5.4 \\
\hline B & 5.6 & 5.9 & 6.7 & 7.5 & 6.3 & 5.2 & 6.1 & 6.4 \\
\hline C & 5.7 & na & 5.3 & 5.0 & 7.0 & na & 7.7 & 4.5 \\
\hline D & 8.6 & 9.1 & 9.3 & 8.7 & 6.9 & 6.3 & 6.8 & 6.3 \\
\hline E & 7.7 & 8.1 & 7.9 & 5.2 & 4.4 & 5.7 & 4.4 & 2.4 \\
\hline F & 4.7 & 3.3 & 5.0 & 5.3 & 3.9 & 0.9 & 3.5 & 4.0 \\
\hline G & 4.2 & 4.1 & 3.6 & na & 3.7 & 0.9 & 3.0 & na \\
\hline H & 5.6 & 5.5 & 4.7 & 6.0 & 4.4 & 2.2 & 3.7 & 4.5 \\
\hline I & 4.7 & 4.3 & 3.9 & 5.6 & 3.7 & 1.0 & 2.9 & 3.4 \\
\hline J & 5.1 & 4.6 & 4.2 & 8.0 & 3.8 & 2.2 & 3.3 & 4.3 \\
\hline K & 4.5 & 4.4 & 4.6 & 4.6 & 4.2 & 4.2 & 4.2 & 3.6 \\
\hline L & 4.7 & 4.5 & 4.7 & 4.6 & 4.3 & 4.2 & 4.3 & 3.7 \\
\hline M & 4.6 & 4.4 & 4.5 & 4.5 & 4.3 & 4.2 & 4.3 & 3.6 \\
\hline N & 4.6 & 4.7 & 4.4 & 4.5 & 4.3 & 4.2 & 4.2 & 3.7 \\
\hline O & 4.6 & 4.5 & 4.5 & 4.5 & 4.3 & 4.2 & 4.2 & 3.6 \\
\hline P & 4.6 & 4.5 & 4.6 & 4.4 & 4.2 & 4.2 & 4.1 & 3.6 \\
\hline Q & 4.5 & 4.5 & 4.5 & 4.5 & 4.2 & 4.2 & 4.2 & 3.7 \\
\hline R & 4.5 & 4.6 & 4.4 & 4.6 & 4.2 & 4.3 & 4.2 & 3.7 \\
\hline S & 4.4 & 4.1 & 4.4 & 4.6 & 4.2 & 4.2 & 4.2 & 3.7 \\
\hline T & 4.5 & 4.3 & 4.4 & 4.5 & 4.2 & 4.1 & 4.2 & 3.8 \\
\hline U & 4.5 & 4.5 & 4.7 & 4.6 & 4.2 & 4.2 & 4.3 & 3.6 \\
\hline V & 4.5 & 4.6 & 4.5 & 4.5 & 4.2 & 3.9 & 4.2 & 3.7 \\
\hline W & 4.7 & 4.5 & na & 4.5 & 4.2 & 4.3 & na & 3.7 \\
\hline X & 4.5 & 4.3 & 4.5 & 4.5 & 4.2 & 4.1 & 4.2 & 3.7 \\
\hline No & & & & & & & \\
\hline
\end{tabular}

na - No data available.

The $\mathrm{Cr}$ and $\mathrm{Pb}$ contents positively correlated in three of the four surveys, showing that elevated concentrations occurred together, especially in the innermost region of the bay. This could indicate that the main entrance of these metals is through the streams.

Since the prevalent circulation in the bay is clock-wise (Plata et al., 1992), the material coming from the Pantanoso and Miguelete streams and from the ANCAP refinery is finally deposited in the most inner region of the bay and in the harbour (Danulat et al., 2002; Muniz et al., 2002), the region presenting the lowest hydrodynamic condition. The main $\mathrm{Cr}$ entrance in the Montevideo coastal zone is through the Pantanoso Stream, into which sewage from tanneries was being discharged without any treatment until some years ago (660 $\mathrm{t} \mathrm{yr}^{-1}$, Lacerda et al., 1998). Chromium is a metal with low biogeochemical mobility, which reduces its potential toxicity (Kennish, 1992). Perhaps the decrease toward the surface sediment observed in some inner stations is due to the closing of some tanneries. Lead has no known biological function, so its effects on biotic communities are very harmful (Kennish, 1992). 

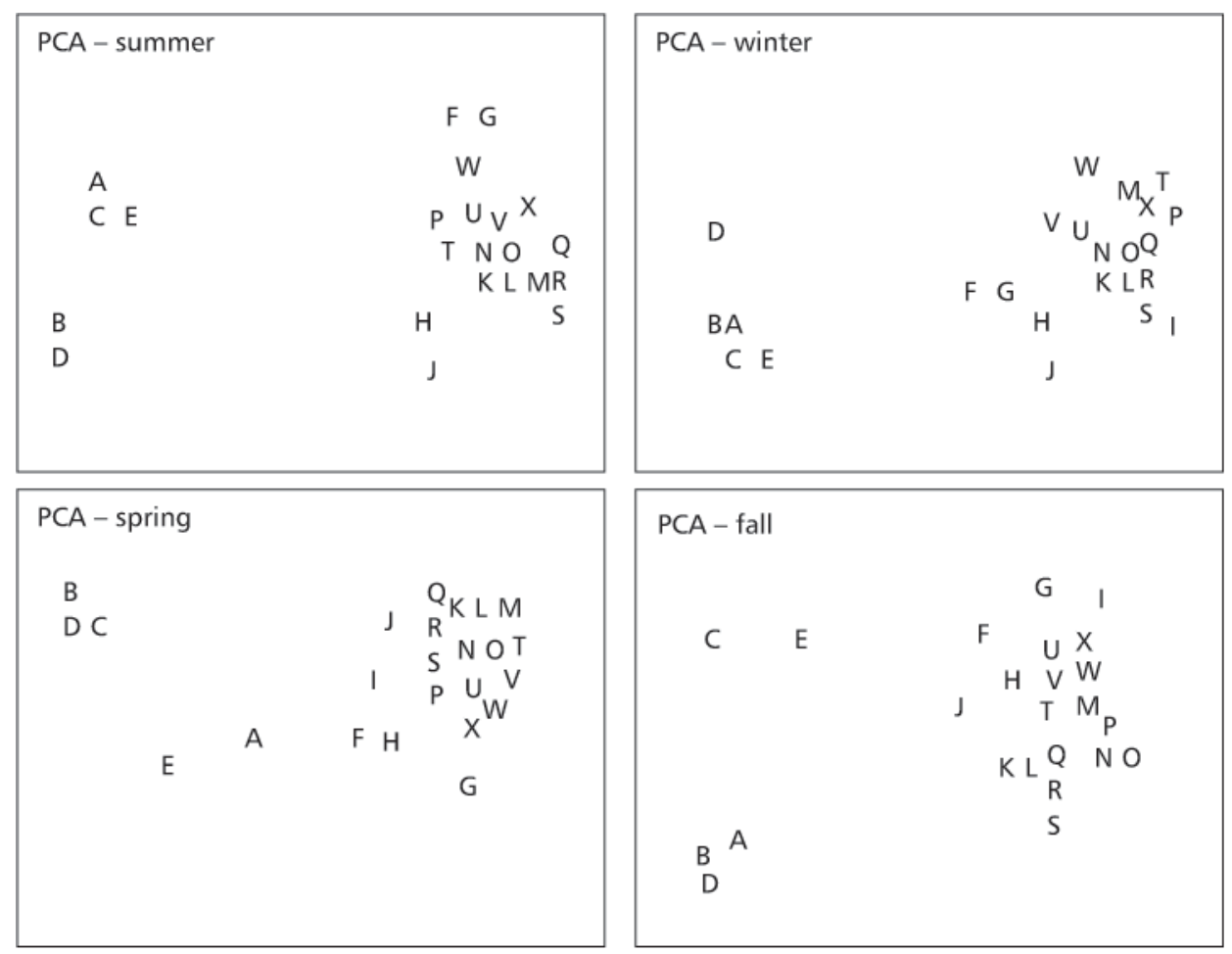

Fig. 6 - Ordination results of the principal component analysis (PCA) based on environmental data, and chromium and lead contents of the 24 sampling stations (A to X) for each survey. For explanation variables and loadings, see Table 3.

According to Moresco \& Dol (1996), the $\mathrm{Pb}$ in Montevideo Bay is mainly distributed among carbonate and oxides fractions. This implies that a great percentage of this metal can be removed from sediments by a decline in $\mathrm{pH}$ (carbonate fraction) or by a decrease of redox potential (oxide fractions), due to the input of organic matter or the depletion of dissolved oxygen content. Data available (Moyano et al., 1993; Moresco \& Dol, 1996) indicate that there has been a considerable increase in $\mathrm{Pb}$ concentrations in sediments as compared to levels previously recorded. These authors reported $\mathrm{Pb}$ concentrations ranging between 0.7 and $146.5 \mathrm{mg}$ $\mathrm{kg}^{-1}$, corresponding the minimum value to the Punta Yeguas zone (considered unpolluted) and the maximum to the mouth of the Miguelete Stream (station $\mathrm{C}$ of this study). In contrast, the minimum and the maximum $\mathrm{Pb}$ concentrations recorded in the present study for the same area were around 40 and $300 \mathrm{mg} \mathrm{kg}^{-1}$, respectively. The increasing urbanization of this region could be responsible for the introduction of great amounts of $\mathrm{Pb}$ coming from urban sewage, city runoff, marine traffic, and the ANCAP petroleum refinery $\left(0.36 \mathrm{t} \mathrm{yr}^{-1}\right.$, Moyano et al., 1993).

Unfortunately, background levels for sediments of the Montevideo region do not exist, so comparing results was difficult. In spite of this situation, we compared our results with the sediment quality guidelines proposed for several metals by different North American agencies and authors (Table 4). Taking into account the results of the analyses, the inner region of Montevideo Bay was observed to be highly polluted, whereas, Punta Carretas, Punta Yeguas, and the outermost stations of the bay can be considered as moderated polluted. The only exception is for $\mathrm{Cr}$ content, which according to Long et al. (1995) makes this external region considered as not polluted (Table 4). The $I_{\text {geo }}$ values calculated for the data also confirmed the above trend. 
Generalizations involving metal concentrations at a regional level are difficult, since different authors do not always use the same analytical procedures and, also, small differences in geological and environmental characteristics can result in great metal concentration disparities (Lacerda et al., 1988).

Nevertheless, the comparison of contaminant concentrations observed during this study with those reported for similar environments in European, and North and South Atlantic estuaries (Table 5) indicates that levels and ranges of variation in our data are similar to those reported in sites with high anthropogenic impact. Indeed, $\mathrm{Cr}$ and $\mathrm{Pb}$ concentrations in the inner Montevideo Bay stations are the highest reported for coastal sediments in this part of the South Atlantic Ocean.

Taking into account both our results and those in the literature, we can affirm that the whole area of Montevideo Coastal Zone is affected by the heavy metals here studied. It is important to emphasize that a noticeable enrichment of $\mathrm{Pb}$ was detected, especially in the Punta Yeguas region, which a priori was considered a pristine area. The fact that the Punta Carretas and Punta Yeguas zones have shown similar values for heavy metals could indicate that their input is not only caused by city effluents.

TABLE 3

Results of the PCA analysis performed for the four data sets analyzed on the Montevideo coastal zone. \% Variation, percentage of explanation of each axis, and loadings of the principal variables analyzed. See Table 1 for the explanation of variable abreviation.

\begin{tabular}{|l|c|c|c|c|c|c|c|c|}
\hline \multicolumn{4}{|c|}{ Summer } & \multicolumn{2}{c|}{ Winter } & \multicolumn{2}{c|}{ Spring } & \multicolumn{2}{c|}{ Fall } \\
\hline & Axis I & Axis II & Axis I & Axis II & Axis I & Axis II & Axis I & Axis II \\
\hline \% Variation & 57.7 & 15.4 & 42.5 & 25.7 & 55.0 & 18.7 & 47.5 & 22.6 \\
\hline Depth & .120 & -.100 & .334 & .112 & .180 & .180 & .113 & .060 \\
\hline Temperature & -.298 & .297 & -.011 & .260 & .056 & -.039 & .085 & -.315 \\
\hline Salinity & .321 & -.240 & .269 & .150 & .303 & .250 & .170 & -.200 \\
\hline $\mathrm{pH}$ & .110 & -.090 & .279 & .048 & .170 & .180 & .201 & -.183 \\
\hline Oxygen & .398 & .025 & -.050 & -.472 & .457 & -.011 & .251 & .234 \\
\hline \% Clay & -.148 & -.386 & -.005 & .204 & -.383 & .122 & .003 & -.250 \\
\hline \% TOM & -.377 & -.157 & -.110 & .483 & -.370 & .248 & -.105 & -.464 \\
\hline $\mathrm{Eh}$ & .420 & .100 & -.227 & -.467 & .300 & -.150 & .409 & .051 \\
\hline $\mathrm{Cr}$ & -.429 & -.201 & -.448 & .258 & -.200 & .008 & -.350 & -.365 \\
\hline $\mathrm{Pb}$ & -.512 & -.100 & -.534 & .273 & -.529 & .124 & -.519 & -.280 \\
\hline
\end{tabular}

TABLE 4

Different sediment quality guidelines for chromium and lead proposed by different authors (adapted from DellValls \& Chapman, 1998) and mean annual value in inner Montevideo Bay (IMB) and outermost Montevideo Bay and adjacent coastal zone (MCZ). Mean value is generated between all the observations made in this study.

\begin{tabular}{|c|c|c|c|c|c|c|}
\hline Pollutant & \multicolumn{1}{|c|}{ NP } & MP & HP & IMB & MCZ \\
\hline \multirow{3}{*}{$\mathrm{Cr}$} & $\mathrm{A}$ & $<25$ & $25-75$ & $>75$ & 315.6 & 46.36 \\
\cline { 2 - 7 } & $\mathrm{B}$ & $<22$ & $22-111$ & $>111$ & & \\
\cline { 2 - 7 } & $\mathrm{C}$ & $<80$ & $80-145$ & $>145$ & & 46.37 \\
\hline \multirow{3}{*}{$\mathrm{Pb}$} & $\mathrm{A}$ & $<40$ & $40-60$ & $>60$ & 211.5 & \\
\cline { 2 - 7 } & $\mathrm{B}$ & $<23$ & 31 & $>250$ & & \\
\cline { 2 - 7 } & $\mathrm{C}$ & $<35$ & $35-110$ & $>110$ & & \\
\hline
\end{tabular}

A = EPA-USA (US Army Corps Of Engineers, 1977); B = Persaud et al., 1989; C = Long et al., 1995;

$\mathrm{NP}=$ not polluted; $\mathrm{MP}=$ moderate polluted; $\mathrm{HP}=$ highly polluted. All values are in $\mathrm{mg} \mathrm{kg}^{-1}$ of dry sediment. 
TABLE 5

Range of variation of $\mathrm{Cr}$ and $\mathrm{Pb}$ of surface sediments in different environments, especially in South America.

\begin{tabular}{|l|c|c|c|c|}
\hline \multicolumn{1}{|c|}{ Location } & $\begin{array}{c}\text { Cr } \\
(\mathbf{m g} / \mathbf{k g})\end{array}$ & $\begin{array}{c}\text { Pb } \\
(\mathbf{m g} / \mathbf{k g})\end{array}$ & Reference & Status \\
\hline South Californian Coast & 2.5 & 4.5 & Thompson et al., 1987 & unpolluted \\
\hline Rhine River, Germany & 47 & 30 & Novotny, 1995 & n.d. \\
\hline Richards Bay Harbour & $10-295$ & n.a. & Vermeulen \& Wepener, 1999 & Unpoll-polluted \\
\hline Patos Lagoon, Brazil & $8-337$ & $8-267$ & Baisch et al., 1988 & Unpoll-polluted \\
\hline Jurujuba Sound, Brazil & $10-223$ & $5-123$ & Baptista Neto et al., 2000 & Unpoll-polluted \\
\hline Bahia Blanca, Argentina & n.a. & $13-17$ & Villa, 1988 & Unpolluted \\
\hline Carrasco Creek, Uruguay & $10-807$ & $17-73$ & Lacerda et al., 1998 & Unpoll-polluted \\
\hline Montevideo Bay, inner & n.a. & $40-148$ & Moresco \& Dol, 1996 & Polluted \\
\hline Montevideo Bay, outer & n.a. & $13-34$ & Moresco \& Dol, 1996 & Polluted \\
\hline Montevideo Bay, inner & 57 & $3.1-35$ & Moyano et al., 1993 & Polluted \\
\hline Montevideo Costal Zone & 0.8 & 0.92 & Moyano et al., 1993 & Unpolluted \\
\hline Montevideo Harbour & $83-253$ & $44-128$ & Danulat et al., 1998 & Polluted \\
\hline Montevideo Bay, inner & $68-1062$ & $99-365$ & This study & $?$ \\
\hline Montevideo Coastal Zone & $37-50$ & $38-56$ & This study & $?$ \\
\hline
\end{tabular}

n.a. - not analysed; n.d. - not defined; Status = defined by the author.

We cannot forget that the Montevideo coastal zone is part of a broad ecosystem that receives input of contaminants and organic load from several industrialized cities like Buenos Aires and São Paulo, throughout the Paraná-Uruguay watershed.

\section{IMPLICATIONS AND CONCLUSIONS}

The analysis of trace metals in sediment samples from the Montevideo coastal area allowed us to define some aspects of the geographical distribution of these contaminants and identify some areas with high concentrations.

The PCA results showed clearly the division of the study area into two well defined regions which, in turn reflect, not only the degree of disturbance due to anthropogenic activities but also the different characteristics of these benthic environments. On the other hand, no important temporal variations were detected in this portion of the Montevideo coastal zone.

We can affirm with some degree of confidence, that the Punta Carretas submarine sewage pipe is not the main source of metal input in this ecosystem, since the metal load recorded in Punta Yeguas is similar to those recorded in Punta Carretas. The smaller variation in metal concentrations observed at the outermost stations of Montevideo Bay, Punta Carretas, and Punta Yeguas is the result of more homogeneous environmental characteristics than those in the inner region of the bay.

If we consider the inner region of the bay by some of the sediment quality guidelines (SQGs) based on toxicity tests that imply potentially adverse biological effects (Long et al., 1995; MacDonald et al., 1996) we observe that it always presents $\mathrm{Cr}$ and $\mathrm{Pb}$ values above the PEL level and sometimes also above the ER-M level. The outer region of Montevideo Bay and the adjacent coastal zone present $\mathrm{Cr}$ values below the TEL level, and $\mathrm{Pb}$ values between TEL and PEL levels. Toxicity rarely occurs below the TEL level but it occurs frequently above the PEL, so that it is between the two levels that toxicity probably occurs. The ER-M is the effects range medium or the $50^{\text {th }}$ percentile values in the effects data set and is always higher than the PEL. These results coincide, in part, with those observed for the benthic fauna of Montevideo Bay (Muniz et al., 2000) and the adjacent coastal zone (Venturini et al., 2004). 
The authors observed that the innermost region of the bay is almost defaunated, presenting only nematodes, and that richness and diversity increase in the outer bay and in the external coastal zone.

Since the area is ecologically attractive to commercially important species like the white croaker, Micropogonias furnieri, that stands second in national landings and is the main species captured through coastal trawling (Acuña et al., 1997), we recommend more investigations on this topic, particularly about metal distribution in the local biota, in order to evaluate conditions either risky or harmful to human health. Recently, Viana (2001) detected $\mathrm{Hg}$ and $\mathrm{Zn}$ accumulation in fishes from the Montevideo coast and maximum $\mathrm{Cu}$ and $\mathrm{Zn}$ levels in the mullet Mugil platanus, an iliophagous species.

Finally, it is important to stress that this data set would be useful and should be taken into account by the Municipal Government as it considers the construction of the new submarine sewage pipe in the Punta Yeguas region.

Acknowledgment - The study was funded by the Intendencia Municipal de Montevideo (IMM) by Comisión Sectorial de Investigación Científica (CSIC) of Uruguay and IAI-SACC project. The Uruguayan Army is acknowledged for the use of its facilities during field work. We also would like to express our gratitude to several colleagues of the Oceanología Sección of Facultad de Ciencias, Montevideo, Uruguay, for their help in various stages of field and laboratory work, and especially to M. Rodríguez, G. Lacerot and A. Martínez.

\section{REFERENCES}

ACUÑA, A., ARENA, G., BEROIS, N., MANTERO, G., MASELLO, A., NION, H., RETTA, S. \& RODRÍGUEZ, M., 1997, La corvina (Micropogonias furnieri): ciclo biológico y pesquerias en el Río de la Plata y su frente oceánico. In: P. G. Wells \& G. R. Daborn (eds.), The Río de la Plata: an environmental overview. An EcoPlata project background report. Dalhousie University, Halifax, Nova Scotia, Canada.

BAISCH, P. R. N., NIENCHESKI, L. F. H. \& LACERDA, L. D., 1988, Trace metal distribution in sediments of the Patos Lagoon estuary, Brazil. In: U. Seeliger, L. D. Lacerda \& S. R. Patchineelam (eds.), Metals in Coastal Environments of Latin America. Springer Verlag, Berlin.

BAPTISTA NETO, J. Á., SMITH, B. J. \& MCALLISTER, J. J., 2000, Heavy metal concentrations in surface sediments in a nearshore environment, Jurujuba Sound, Southeast Brazil. Environ. Poll., 109: 1-9.

BYERS, S. C., MILLS, E. L. \& STEWART, P. L., 1978, A comparison of methods to determining organic carbon in marine sediments, with a suggestion for a standard method. Hydrobiol., 58: 43-57.
DANULAT, E., MUNIZ, P., YANNICELLI, B., GARCÍA, J. \& MEDINA, G., 1998, Mejoramiento ambiental del Puerto de Montevideo. Reporte de técnico de Proyecto. Facultad de Ciencias-Administración Nacional de Puertos.

DANULAT, E., MUNIZ, P., GARCÍA-ALONSO, J. \& YANNICELLI, B., 2002, First assessment of the highly contaminated Harbour of Montevideo (Uruguay). Mar. Poll. Bull., 44: 554-565.

DELLVALlS, T. A. \& CHAPMAN, P. M., 1998, Site-specific sediment quality values for the Gulf of Cádiz (Spain) and San Francisco Bay (USA), using the sediment quality triad and multivariate analysis. Ciencias Marinas, 24: 313-326.

DUCK, R. W. \& WEWETZER, F. K., 2001, Impact of frontal systems on estuarine sediment and pollutant dynamics. The Science of Total Environment, 266: 23-31.

EPA (Environmental Protection Agency), 1977, Implementation Manual for Section 103 Public Law 92-532: Marine Protection, Research and Sanctuaries Act of 1972. U.S. Army Corps of Engineers, Environmental Effects Laboratory, Waterways Experiment Section, Vicksburgs, MS.

EPA (Environmental Protection Agency), 1990, Microwave assisted and digestion of aqueous samples and extracts. SW-846. Method 3015 and 3051 . Test methods for evaluating solid waste. US Environmental Protection Agency, Washington, DC.

FOLK, R. L. \& WARD, W. C., 1957, Brazos River bar: a study of the significance of grain size parameters. J. Sedim. Petrol., 27: 3-26.

FRAMIÑAN, M. E. \& BROWN, O. B., 1996, Study of the Río de la Plata turbidity front. Part I: Spatial and temporal distribution. Cont. Shelf Res., 16: 1259-1282.

FRAMIÑAN, M. E., ETALA, M. P., ACHA, E. M., GUERRERO, R. A., LASTA, C. A. \& BROWN, O. B., 1999, Physical characteristics and processes of the Río de la Plata estuary. In: G. M. E. Perillo, M. C. Piccolo \& M. PinoQuivira (eds.), Estuaries of South America: their geomorphology and dynamics. Springer-Verlag, Berlin.

GRASSHOFF, K., 1983, Determination of oxygen. In: K. Grasshoff, M. Ehrjardt \& K. V. Kremling (eds.), Methods of seawater analysis. Weinheim, Verlag Chemie.

GRAY, J. S., 1981, The ecology of marine sediments. Cambridge University Press, London.

GUERRERO, R. A., ACHA, E. M., FRAMIÑAN, M. B. \& LASTA, C. A., 1997, Physical oceanography of the Rio de la Plata estuary, Argentina. Cont. Shelf res, 17: 727-742.

HERR, C. \& GRAY, N. F., 1997, Sampling riverine sediments impacted by acid mine drainage: problems and solutions. Environ. Geol., 29: 37-45.

IENO, E. N. \& BASTIDA, R. O., 1998, Spatial and temporal patterns in coastal macrobenthos of Samborombon Bay, Argentina: a case study of very low diversity. Estuaries, 21(4B): 690-699.

KENNISH, M. J., 1992, Ecology of estuaries: anthropogenic effects. Marine Science Series. CRC Press, Inc. USA.

LACERDA, L. D., SOUZA, C. M. M. \& PESTANA, M. H. D., 1988, Geochemical distribution of $\mathrm{Cd}, \mathrm{Cu}$, and $\mathrm{Pb}$ in sediments of estuarine areas along the southern Brazilian coast. In: U. Seeliger, L. D. Lacerda \& S. R. Patchineelam (eds.), Metals in coastal environments of Latin America. Springer Verlag, Berlin. 
LACERDA, L. D., HUERTAS, R., MORESCO, H. F., CARRASCO, G., VIANA, F., LUCAS, R. \& PESSÍ, M., 1998, Trace metal concentrations and geochemical partitioning in arroyo Carrasco wetlands, Montevideo, Uruguay. Geochimica Brasiliensis, 12: 63-74.

LONG, E. R., MACDONALD, D. D., SMITH, S. L. \& CALDER, F. D., 1995, Incidence of adverse biological effects within ranges of chemical concentrations in marine and estuarine sediments. Environ. Manage., 19: 81-97.

LÓPEZ-LABORDE, J., 1997, Marco geomorfológico y geológico del Río de la Plata. In: P. G. Wells \& G. R. Daborn (eds.), The Río de la Plata: an environmental overview. An EcoPlata project background report. Dalhousie University, Halifax, Nova Scotia, Canada.

LÓPEZ-LABORDE, J. \& NAGY, G. J., 1999, Hydrography and sediment transport characteristics in the Río de la Plata. In: G. M. E. Perillo, M. C. Piccolo \& M. Pino-Quivira (eds.), Estuaries of South America: their geomorphology and dynamics. Springer-Verlag, Berlin.

MASELLO, A., SCARABINO, F. \& MENAFRA, R., 1996, Objective C: Benthos. Final technical report. Project ECOPLATA 93-1551.59.

MACDONALD, D. D., CARR, S. R., CALDER, F. D., LONG E. R. \& INGERSOL, C. G., 1996, Development and evaluation of sediment quality guidelines for Florida coastal waters. Ecotoxicology, 5: 253-278.

MORESCO, H. \& DOL, I., 1996, Metales em sedimentos de la Bahia de Montevideo. Revista Asociación de Ciencias Naturales del Litoral, 27: 1-5.

MOYANO, M., MORESCO, H., BLANCO, J., ROSADILLA, M. \& CABALLERO, A., 1993, Baseline studies of coastal pollution by heavy metals, oil and PAHs in Montevideo. Mar. Poll. Bull., 26: 461-464.

MÜLLER, G., 1981, Die Schwermetallbelastung der Sedimente des Neckars und seiner Nebenflusse: eine Bestandsaufnahme. Chemical Zeitung, 105: 157-164.

MUNIZ, P., VENTURINI, N., RODRÍGUEZ, M., MARTÍNEZ, A., LACEROT, G. \& GÓMEZ, M., 2000, Benthic communities in a highly polluted urban bay. In: P. J. Milón, C. T. Delgado, L. V. Paredes \& F. V. Benavides (eds.), Ecología y desarrollo sostenible: reto de América Latina para el tercer milenio. Memorias del IV Congreso latinoamericano de Ecología. Arequipa, Perú.

MUNIZ, P. \& VENTURINI, N., 2001, Spatial distribution of the macrozoobenthos in the Solis Grande Stream estuary (Canelones-Maldonado, Uruguay). Braz. J. Biol., 61: 409-420.

MUNIZ, P., VENTURINI, N. \& MARTÍNEZ, A., 2002, Physicochemical characteristics and pollutants of the benthic environment of Montevideo Coastal Zone, Uruguay. Mar. Poll. Bull., 44: 962-968

NAGY, G. J., LOPEZ-LABORDE, J. \& ANASTASIA, L., 1987, Caracterización de ambientes en el Río de la Plata Exterior (salinidad y turbiedad óptica). Inv. Oceanológicas, 1: 31-56.

NAGY, G. J., MARTÍNEZ, C. M., CAFFERA, R. M., PEDROSA, G., FORBES, E. A., PERDOMO, A. C. \& LÓPEZ-LABORDE, J., 1997, Hydroclimatic setting of the Río de la Plata. In: P. G. Wells \& G. R. Daborn (eds.), The Río de la Plata: an environmental overview. an ecoplata project background report. Dalhousie University, Halifax, Nova Scotia, Canada.
NOVOTNY, V., 1995, Diffuse sources of pollution by toxic metals and impact on receiving waters. In: W. Salomons, U. Förstner \& P. Mader (eds.), Heavy Metals: problems and solutions. Springer-Verlag, Berlin.

PEARSON, T. H. \& STANLEY, S. O., 1979, Comparative measurement of the redox potential of marine sediments as a rapid means of assessing the effect of organic pollution. Mar. Biol., 53: 371-379.

PERSAUD, D., JAAGUMAGI, R. \& HAYTON, A., 1989, Development of Provincial Sediment Quality Guidelines. Ontario Ministry of the Environment, Water Resources Branch, Aquatic Biology Section, Ontario.

PEZESHKI, S. R. \& DELAUNE, R. D., 1993, Effects of soil hypoxia and salinity on gas exchange and growth of Spartina patens. Mar. Ecol. Progr. Ser., 96: 75-81.

PLATA, A., KURUCZ, A., VERA, C., SUÁREZ, R., URES, C. \& PINTOS, J., 1992, Circulación y renovación del agua en la Bahía de Montevideo. Progress Report. Project URU/8/007. Organismo Internacional de Energía Atómica (OIEA), Vienna.

RUIZ, F., 2001, Trace metals in estuarine sediments from the southwestern Spanish coast. Mar. Poll. Bull., 42: 482-490.

SHARP, J. H., 1973, Size classes of organic carbon in seawater. Limnol. Oceanogr., 18: 441-447.

SOMMARUGA, R., 1987, Dinámica de la interfase aguasedimento en un sistema eutrófico: lago Ton-Ton (Canelones, Uruguay). Bachelor Thesis, Facultad de Humanidades y Ciencias, Universidad de la República, Montevideo, 93p.

STATSOFT, INC., 1995, STATISTICA for the Windows Operating System. Release 5. StatSoft, Inc., Tulsa OK, USA.

SUGUIO, K., 1973, Introdução à sedimentologia. Edgard Blucher, São Paulo.

THOMPSON, E. A., LAUGHLIN, J. D. \& TSUKADA, D. T., 1987, Reference site survey. Southern California Coastal Water Research Project. Technical Report. Long Beach, California. Us Army Corps of Engineers., 1977, Implementation manual for Section 103 of Public Law 92532: Marine Protection, Research and Sanctuaries Act of 1972, July 1977. Us Army Corps of Engineers, Environmental Effects Laboratory, Waterways Experiment Section, Vicksburg, MS.

VENTURINI, N., MUNIZ, P. \& RODRÍGUEZ, M., 2004, Macrobenthic subtidal communities in relation to sediment pollution: the phylum-level meta-analysis approach in a south-eastern coastal region of south América. Mar Biol., 144: 119-126.

VERMEULEN, L. A. \& WEPENER, V., 1999. Spatial and temporal variations of metals in Richards Bay Harbour (RBH), South Africa. Mar. Poll. Bull., 39: 304-307.

VIANA, F., 2001, Metales pesados en peces de la costa de Montevideo, Uruguay. Master Thesis. Facultad de Ciencias, Sección Oceanografía, Montevideo, Uruguay.

VILLA, N., 1988, Sapatial distribution of heavy metals in seawater and sediments from coastal areas of the southern Buenos Aires Province, Argentina. In: U. Seeliger, L. D. Lacerda \& S. R. Patchineelam (eds.), Metals in coastal environments of Latin America. Springer Verlag, Berlin.

ZOBELL, C. E., 1946, Studies on redox potential of marine sediments. Bulletin of the American Association of Petrology and Geology, 30: 477-513. 